\title{
Penggunaan Konjungsi dan Makna Teks Terjemahan Surat Al-Baqarah
}

\author{
Ummul Khair
}

Sekolah Tinggi Agama Islam Negeri (STAIN) Curup ummulkhair1213@gmail.com

\begin{tabular}{ll}
\hline Article info & A B S T R A C T \\
\hline Article history: & The purpose of this study was to 1) describe the type of conjunction in the \\
Received: 22-03-2018 $:$ 12-09-2018 & translation of the sura Al-Baqarah and 2) describe the meaning of the \\
Accepted: 12-12-2018 & conjunction contained in the surah Al-Baqarah. The method of collecting \\
& data uses the read, see, and note method. With basic techniques in the form \\
& of determining elements (PUP) techniques, marking reading techniques, \\
& and extension techniques. The results of the analysis show: coordinative \\
& conjunction dan (78); interfaith conjunction (25); last intra-coordinative \\
& sentence conjunction lalu (6); the use of interfaith conjunctions even \\
& though padahal (6); coordinative in sentences conjunction tetapi (4); \\
& coordinative in sentences conjunction kemudian (4); coordinative in \\
& sentences connective bahwa (3); subordinate in sentences conjunction \\
& maka (2); subordinate in sentences conjunctions so agar (4); interfaith \\
& conjunction selain (2); between interfaith conjunctions lagi (2); \\
& subordinate in sentences conjunction ketika (3); subordinate conjunction \\
& jika (2); subordinate sub-syntax conjunction jikalau (2); subordinate \\
& conjunction sebab (2); subordinate conjunction dengan (2); subordinate \\
& conjunction sebagaimana (2). Analysis of the text of the translation of the \\
& letter of the Albaqarah juz 1, there are 22 uses of the word conjunction.
\end{tabular}

Keywords: Al Quran

Al-Baqarah conjunction sentences word

Tujuan penelitian ini adalah untuk 1) mendeskripsikan jenis konjungsi pada terjemahan surah Al-Baqarah dan 2) memaparkan makna konjungsi yang terkandung dalam surah Al -Baqarah. Metode pengumpulan data menggunakan metode baca, simak, dan catat. Dengan teknik dasar berupa teknik pilah unsur penentu (PUP), teknik baca markah, dan teknik perluas. Hasil analisis menunjukkan: konjungsi koordinatif dan (78); konjungsi antarkalimat (25); konjungsi intra kalimat koordinatif lalu (6); penggunaan konjungsi antarkalimat padahal (6); konjungsi intrakalimat koordinatif tetapi (4); konjungsi intrakalimat koordinatif kemudian (4); kata penghubung intrakalimat koordinatif bahwa (3); konjungsi intrakalimat subordinatif maka (2); konjungsi intrakalimat subordinatif agar (4); konjungsi antarkalimat selain (2); konjungsi antarkalimat lagi (2); konjungsi intrakalimat subordinatif ketika (3); konjungsi subordinatif jika (2); konjungsi intrakalimat subordinatf jikalau (2); konjungsi subordinatif sebab (2); konjungsi subordinatif dengan (2); konjungsi subordinatif sebagaimana (2). Analisis teks terjemahan surat Albaqarah juz 1, terdapat 22 penggunaan kata konjungsi.

Copyright (@ 2018 Institut Agama Islam Negeri Syekh Nurjati Cirebon. All rights reserved.

\section{PENDAHULUAN}

Alquran merupakan kitab suci umat Islam yang berisi kumpulan firman Allah yang diturunkan kapada Nabi Muhammad Saw. Alquran diturunkan untuk menjadi pedoman manusia dalam menata kehidupan supaya memperoleh kebahagiaan di dunia dan akhirat. Alquran ditulis dengan menggunakan bahasa Arab. Bahasa Arab 


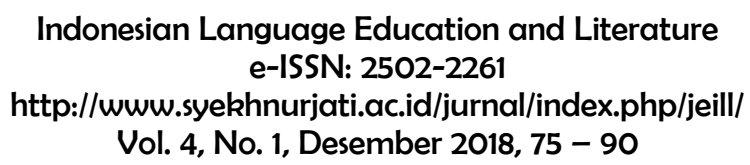

juga mengenal konjungsi (Ummi \& Mulyaningsih, 2016). Salah satu fungsi konjungsi adalah sebagai unsur kohesi (Hartanto, 2015). Bahasa memiliki peran yang sangat penting bagi kehidupan manusia. Keberadaan bahasa dalam kehidupan masyarakat erat hubungannya dengan pemakainya. Manusia sangat membutuhkan bahasa sebagai alat untuk menyampaikan ide-ide. Seiring dengan perkembangan kebudayaan, masyarakat, dan teknologi zaman ini bahasa tumbuh, hidup, dan berkembang biak, baik secara lisan maupun tulisan. Dengan bahasa masyarakat dapat mengkomunikasikan pesan yang hendak disampaikan pada masyarakat lain (Hun \& Hassan, 2017).

\section{METODE}

Penelitian ini akan berfokus pada penggunaan konjungsi terjemahan surat AlBaqarah. Konjungsi dibatasi pada antarkalimat dan intrakalimat. Adapun tujuan penelitian ini adalah 1) mendeskripsikan penggunaan jenis-jenis konjungsi antarkalimat dan intrakalimat pada terjemahan surat Al-Baqarah serta 2) memperjelas makna kalimat terjemahan surat Al-Baqarah berdasarkan konjungsi antarkalimat dan intrakalimat yang digunakan. Metode yang digunakan adalah telaah pustaka, pemaparan, data secara kualitatif deskriptif, menggunakan metode baca, simak, dan catat. Dengan teknik dasar berupa teknik pilah unsur penentu (PUP), teknik baca markah, dan teknik perluas makna.

\section{HASIL DAN PEMBAHASAN}

\section{Ayat 1-5 tentang takwa dan iman}

Alif laam miin.

Pada terjemaham Al-Quran ayat satu tidak terdapatnya pengunaan konjungsi.

Kitab (Al Quran) ini tidak ada keraguan padanya; petunjuk bagi mereka yang bertaqwa.

Pada terjemaham Al-Quran ayat satu tidak terdapat penggunaan konjungsi.

... (yaitu) mereka yang beriman kepada yang ghaib yang mendirikan shalat dan menafkahkan sebahagian rezki yang kami anugerahkan kepada mereka. 


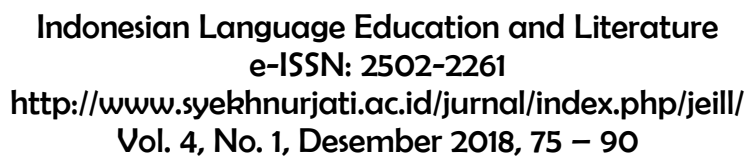

Konjungsi dan pada terjemahan tersebut termasuk konjungsi intrakalimat, yaitu jenis konjungsi koordinatif, yang mempunyai status sederajat. Dengan makna orang yang beriman, mendirikan sholat dan yang menafkahkan sebagian rezekinya di jalan Allah adalah orang yang bertakwa.

... dan mereka yang beriman kepada Kitab (Al Quran) yang telah diturunkan kepadamu Kitab-kitab yang telah diturunkan sebelummu, serta mereka yakin akan adanya (kehidupan) akhirat.

Konjungsi koordinatif dan merupakan konjungsi antarkalimat dengan fungsi konjungsi aditif (gabungan) antarkalimat yang sederajat pada arti ayat penanda hubungan penambahan keterangan. Konjungsi koordinatif serta dalam kalimat terjemahan menghubungkan klausa menyatakan hubungan yang sederajat, antara kitab dengan kehidupan ahirat.

Mereka itulah yang tetap mendapat petunjuk dari Tuhan mereka, dan merekalah orang-orang yang beruntung.

Konjungsi koordinatif dan pada terjemahan termasuk konjungsi intrakalimat, yaitu yang mempunyai status sederajat. Dengan makna orang yang mendapat petunjuk, merekalah orang-orang yang beruntung.

\section{Ayat 6-7 tentang kufur}

Sesungguhnya orang-orang kafir, sama saja bagi mereka, kamu beri peringatan atau tidak kamu beri peringatan, mereka tidak juga akan beriman.

Konjungsi subordinatif sesungguhnya pada data berfungsi menyatakan hubungan penyungguhan. Penggunaan konjungsi sesungguhnya, termasuk konjungsi antarkalimat yang menyatakan keadaan yang sebenarnya, yaitu terhadap orang-orang kafir sama juga diberi peringatan. Konjungsi koordinatif atau pada data menyatakan makna pemilihan. Penggunaan konjungsi atau dalam kalimat terjemahan, menghubungkan dua klausa menyatakan pemilihan, yaitu orang kafir diberi peringatan atau tidak sama saja dia tetap tidak akan beriman.

Allah telah mengunci-mati hati dan pendengaran mereka, dan penglihatan mereka ditutup. Dan bagi mereka siksa yang amat berat. 
Konjungsi dan pada terjemahan termasuk konjungsi intrakalimat, yaitu jenis konjungsi koordinatif menghubungkan klausa. Konjungsi ini mempunyai status sederajat, yaitu mengunci mati hati dan pendengaran mereka. Konjungsi dan pada tejemahan termasuk konjungsi intrakalimat, yaitu jenis konjungsi koordinatif yang menghubungkan klausa. Konjungsi ini mempunyai status sederajat, yaitu mengunci pendengaran dan penglihatan mereka. Konjungsi dan pada terjemahan termasuk konjungsi antarkalimat, yaitu jenis konjungsi aditif (gabungan), yang mempunyai status sederajat. Terhadap perbuatan dan ganjaran umatnya.

\section{Ayat 8-13 tentang Nifaq I}

Di antara manusia ada yang mengatakan: Kami beriman kepada Allah dan Hari kemudian, pada hal mereka itu sesungguhnya bukan orang-orang yang beriman.

Konjungsi dan pada terjemahan ayat ke- 8 termasuk konjungsi antarkalimat, yaitu jenis konjungsi aditif (gabungan). Konjungsi berfungsi mempunyai status sederajat, yaitu dengan makna sama-orang yang tidak beriman. Konjungsi sesungguhnya pada terjemahan ayat ke-8 termasuk konjungsi antarkalimat yang mempunyai status sederajat.

Allah dan orang-orang yang beriman, padahal mereka hanya menipu dirinya sendiri sedang mereka tidak sadar.

Konjungsi dan pada terjemahan ayat ke-9 termasuk konjungsi antarkalimat, yaitu jenis konjungsi aditif (gabungan). Konjungsi ini mempunyai status sederajat bermakna orang - orang yang beriman. Konjungsi padahal pada terjemahan ayat ke9 termasuk konjungsi antarklausa, yaitu jenis konjungsi intrakalimat, koordinatif. Konjungsi situasi ini menjelaskan suatu perbuatan yang terjadi atau berlangsung dalam keadaan tertentu.

Dalam hati mereka ada penyakit, lalu ditambah Allah penyakitnya; dan bagi mereka siksa yang pedih, disebabkan mereka berdusta.

Konjungsi lalu pada terjemahan ayat ke-10 termasuk konjungsi antarklausa, yaitu jenis konjungsi subordinatif jenis urutan. Konjungsi ini menjelaskan suatu urutan berikutnya, yaitu sifat yang terlarang. Konjungsi dan pada terjemahan ayat ke-10 


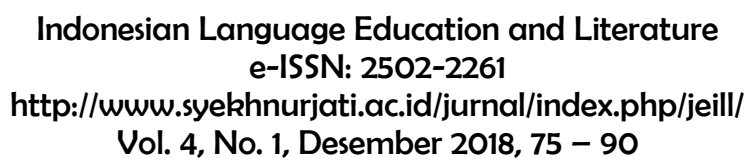

termasuk konjungsi antarkalimat, yaitu jenis konjungsi aditif (gabungan). Konjungsi ini mempunyai status sederajat, yaitu tentang sifat terlarang dalam berdusta.

Dan bila dikatakan kepada mereka:"Janganlah kamu membuat kerusakan di muka bumi. Mereka menjawab: "Sesungguhnya kami orang-orang yang mengadakan perbaikan.

Konjungsi dan merupakan konjungsi antarkalimat dengan fungsi konjungsi aditif (gabungan) antarkalimat yang sederajat pada arti ayat tentang melarang melakukan perusakan. Konjungsi sesungguhnya pada terjemahan termasuk konjungsi antarkalimat, yaitu yang mempunyai status sederajat. Terhadap perbuatan sama-sama ke arah perbaikan.

Ingatlah, sesungguhnya mereka itulah orang-orang yang membuat kerusakan, tetapi mereka tidak sadar.

Konjungsi sesungguhnya pada terjemahan ayat ke-12 termasuk konjungsi antarkalimat yang masih berhubungan dengan ayat sebelumnya, yaitu yang menyatakan keadaan yang sebenarnya tentang status sederajat, tentang melarang merusak. Konjungsi tetapi merupakan konjungsi antarkalimat. Keaadaan yang menyatakan bertentangan dengan keadaan sebelumnya. Tentang kesadaran akan membuat kerusakan.

Apabila dikatakan kepada mereka: "Berimanlah kamu sebagaimana orang-orang lain telah beriman." Mereka menjawab: "Akan berimankah kami sebagaimana orang-orang yang bodoh itu telah beriman?" Ingatlah, sesungguhnya merekalah orang-orang yang bodoh; tetapi mereka tidak tahu.

Konjungsi sebagaimana menyatakan perbandingan yang berfungsi menghubungkan dua hal dengan cara membandingkan kedua hal tentang suruhan untuk beriman. Konjungsi sesungguhnya pada terjemahan ayat ke-11 termasuk konjungsi antarkalimat. Konjungsi ini mempunyai hubungan keadaan yang sebenarnya, yakni tentang orang yang berkata beriman sesungguhnya tidak, maka ia adalah bodoh. Penggunaan konjungsi tetapi yang menyatakan makna perlawanan. 


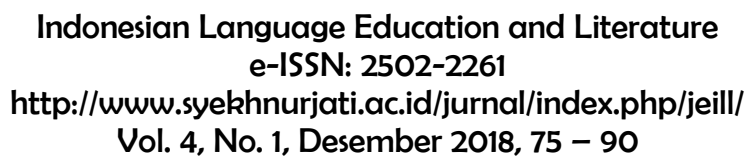

\section{Ayat 14-20 tentang Nifaq II}

Dan bila mereka berjumpa dengan orang-orang yang beriman, mereka mengatakan: "Kami telah beriman. Dan bila mereka kembali kepada syaitan-syaitan mereka, mereka mengatakan: Sesungguhnya kami sependirian dengan kamu, kami hanyalah berolok-olok.

Konjungsi dan merupakan konjungsi antarkalimat dengan fungsi konjungsi aditif (gabungan) antarkalimat yang sederajat pada arti ayat tentang orang-orang yang beriman. Konjungsi dan pada terjemahan termasuk konjungsi antarkalimat, yaitu jenis konjungsi aditif (gabungan). Konjungsi ini mempunyai status sederajat, yaitu dengan makna sama-orang yang kembali kepada rayuan setan. Konjungsi sesungguhnya pada terjemahan termasuk konjungsi antarkalimat. Konjungsi ini mempunyai hubungan keadaan yang sebenarnya, yakni tentang orang yang berolokolok.

Allah akan (membalas) olok-olokan mereka dan membiarkan mereka terombangambing dalam kesesatan mereka.

Konjungsi dan pada terjemahan termasuk konjungsi antarkalimat, yaitu jenis konjungsi aditif (gabungan). Konjungsi ini mempunyai status sederajat, yaitu dengan makna orang yang berolok-olok akan berada dalam kesesatan.

Mereka itulah orang yang membeli kesesatan dengan petunjuk, maka tidaklah beruntung perniagaan mereka dan tidaklah mereka mendapat petunjuk.

Konjungsi subordinatif dengan yang menyatakan hubungan cara yang sesat mendapatkan petunjuk. Konjungsi dan pada terjemahan termasuk konjungsi antarkalimat, yaitu jenis konjungsi aditif (gabungan). Konjungsi ini mempunyai status sederajat, yaitu orang yang membeli kesesatan sehingga akan membuat dagangan mereka tidaklah beruntung.

Perumpamaan mereka adalah orang yang menyalakan api, maka setelah api itu menerangi sekelilingnya Allah hilangkan cahaya (yang menyinari) mereka, dan membiarkan mereka dalam kegelapan, tidak dapat melihat. 


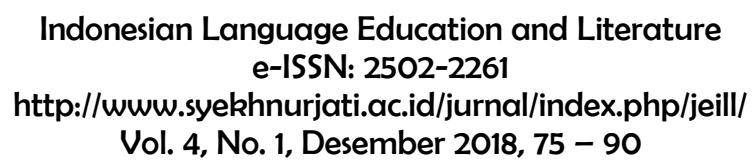

Konjungsi dan pada terjemahan termasuk konjungsi antarkalimat, yaitu jenis konjungsi aditif (gabungan).Konjungsi ini mempunyai status sederajat, yaitu orang yang membeli kesesatan sehingga akan menjadi gelap tidak dapat melihat.

Mereka tuli, bisu dan buta, maka tidaklah mereka akan kembali (ke jalan yang benar).

Konjungsi dan pada terjemahan termasuk konjungsi antarkalimat, yaitu jenis konjungsi aditif (gabungan). Konjungsi ini mempunyai status sederajat, yaitu orang yang tidak mau belajar dan selalu tidak mengetahui sesuatu apa pun.

... atau seperti (orang-orang yang ditimpa) hujan lebat dari langit disertai gelap gulita, guruh dan kilat; mereka menyumbat telinganya dengan anak jarinya, karena (mendengar suara) petir, sebab takut akan mati. Dan Allah meliputi orang-orang yang kafir.

Konjungsi atau yang menyatakan memilih dari dua hal atau lebih. Apakah akan menutup panca indra dari kebenaran Allah? Konjungsi dan pada terjemahan termasuk konjungsi antarkalimat, yaitu jenis konjungsi aditif (gabungan). Konjungsi ini mempunyai status sederajat, yaitu orang yang melindungi dirinya dari keadaan petir dengan menutup telinganya. Konjungsi sebab adalah jenis konjungsi sebab atau kausal, menyatakan umat manusia menutup telinganya karena takut dengan petir. Konjungsi dan pada terjemahan termasuk konjungsi antarkalimat, yaitu jenis konjungsi aditif (gabungan). Konjungsi ini mempunyai status sederajat, yaitu orang yang mendengar petir takut akan mati.

Hampir-hampir kilat itu menyambar penglihatan mereka. Setiap kali kilat itu menyinari mereka, mereka berjalan di bawah sinar itu, dan bila gelap menimpa mereka, mereka berhenti. Jikalau Allah menghendaki, niscaya Dia melenyapkan pendengaran dan penglihatan mereka. Sesungguhnya Allah berkuasa atas segala sesuatu.

Konjungsi dan pada terjemahan termasuk konjungsi antarkalimat, yaitu jenis konjungsi aditif (gabungan).Konjungsi ini mempunyai status sederajat, yaitu orang yang melindungi dirinya dari keadaan petir dengan menutup telinganya. Konjungsi jikalau yang sesuai dengan hubungan makna syarat. Konjungsi ini menyatakan 


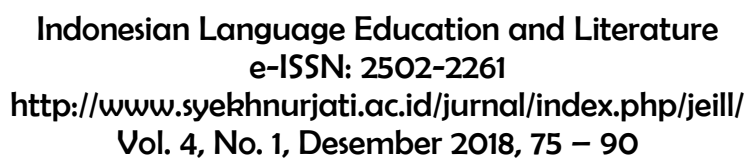

hubungan antarkalimat yang klausa menyatakan syarat terlaksananya sesuatu yang disebut pada klausa utama. Konjungsi jikalau merupakan konjungsi syarat yang menjelaskan bahwa suatu hal dapat terjadi ketika syarat-syarat yang disebutkan itu dipenuhi. Konjungsi dan pada terjemahan termasuk konjungsi antarkalimat, yaitu jenis konjungsi aditif (gabungan). Konjungsi ini mempunyai status sederajat, yaitu yang Allah kehendaki terhadap umatnya. Konjungsi sesungguhnya pada terjemahan termasuk konjungsi antarkalimat, yaitu yang mempunyai hubungan keadaan yang sebenarnya. Terjemahan ini menyatakan bahwa Allahlah yang berkuasa terhadap segala sesuatunya.

\section{Ayat 30-30 tentang malaikat dan khalifah}

Ingatlah ketika Tuhanmu berfirman kepada para Malaikat: "Sesungguhnya Aku hendak menjadikan seorang khalifah di muka bumi." Mereka berkata: "Mengapa Engkau hendak menjadikan (khalifah) di bumi itu orang yang akan membuat kerusakan padanya dan menumpahkan darah, padahal kami senantiasa bertasbih dengan memuji Engkau dan mensucikan Engkau?" Tuhan berfirman: "Sesungguhnya Aku mengetahui apa yang tidak kamu ketahui."

Konjungsi subordinatif ketika menghubungkan klausa yang mempunyai status sederajat dan menyatakan hubungan waktu. Konjungsi sesungguhnya pada terjemahan termasuk konjungsi antarkalimat, yaitu yang mempunyai hubungan keadaan yang sebenarnya. Terjemahan ini menyatakan bahwa Allahlah yang akan menjadikan umatnya seorang khalifah. Konjungsi padahal menyatakan konjungsi situasi menjelaskan suatu perbuatan yang terjadi atau berlangsung dalam keadaan tertentu. Terjemahan ini menyatakan yang senantiasa bertasbih dan memuja Allah. Konjungsi dan pada terjemahan termasuk konjungsi antarkalimat, yaitu jenis konjungsi aditif (gabungan). Konjungsi ini mempunyai status sederajat, bahawa yang menjadi khalifah dimuka bumi bukanlah orang yang suka merusak. Konjungsi sesungguhnya pada terjemahan termasuk konjungsi antarklausa, yaitu yang mempunyai hubungan keadaan yang sebenarnya. Terjemahan ini menyatakan bahwa Allahlah yang mengetahui apa yang umatnya ketahui.

Dan Dia mengajarkan kepada Adam nama-nama (benda-benda) seluruhnya, kemudian mengemukakannya kepada para Malaikat lalu berfirman: "Sebutkanlah kepada-Ku nama benda-benda itu jika kamu mamang benar orang-orang yang benar!" 


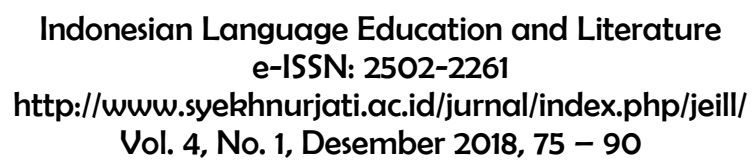

Konjungsi dan pada terjemahan termasuk konjungsi antarkalimat, yaitu jenis konjungsi aditif (gabungan). Terjemahan ini mengajarkan tentang semua nama-nama benda untuk mengetahui suatu melaksanakan perintah Allah dan beriman. Penggunaan konjungsi subordinatif kemudian merupakan urutan akan sesuatu hal atau batas-batas mana perbuatan dapat dilakukan. Konjungsi koordinatif lalu atau hubungan yang menghubungkan klausa yang mempunyai status yang sederajat, merupakan konjungsi urutan. Konjungsi subordinataif jika menyatakan hubungan syarat dengan mengetahui nama benda dana menyatakan adalah orang yang beriman.

Mereka menjawab: "Maha Suci Engkau, tidak ada yang kami ketahui selain dari apa yang telah Engkau ajarkan kepada kami; sesungguhnya Engkaulah Yang Maha Mengetahui lagi Maha Bijaksana.

Penggunaan konjungsi selain merupakan konjungsi pembatasan menyatakan pembatasan terhadap sesuatu hal atau dalam batas-batas mana perbuatan dapat dikerjakan. Konjungsi sesungguhnya pada terjemahan termasuk konjungsi antarklausa, yaitu mempunyai hubungan keadaan yang sebenarnya. Terjemahan ini menyatakan bahwa Allahlah yang maha mengetahui segala sesuatunya. Konjungsi lagi antarkaliamat menyatakan adanya hal atau peristiwa keadaan lain di luar yang sudah dinyatakan. Allah maha mengetahui dan bijaksana.

Allah berfirman: "Hai Adam, beritahukanlah kepada mereka nama-nama benda ini." Maka setelah diberitahukannya kepada mereka nama-nama benda itu, Allah berfirman: "Bukankah sudah Ku katakan kepadamu, bahwa sesungguhnya Aku mengetahui rahasia langit dan bumi dan mengetahui apa yang kamu lahirkan dan apa yang kamu sembunyikan?"

Konjungsi subordinatif maka menghubungkan antarkalimat menyatakan hubungan pengakibatan, yaitu untuk mengetahui semua yang ada di bumi. Konjungsi subordinatif bahwa menghubungkan antarklausa menyatakan hubungan pengakibatan terhadap apa yang dilakukan umat Allah. Konjungsi sesungguhnya pada terjemahan termasuk konjungsi antarkalimat, yaitu yang mempunyai hubungan keadaan yang sebenarnya. Terjemahan ini menyatakan bahwa Allahlah yang mengetahui yang umatnya ketahui, yang ada di bumi dan langit. Konjungsi dan pada tejemahan termasuk konjungsi antarklausa, yaitu jenis konjungsi aditif atau 


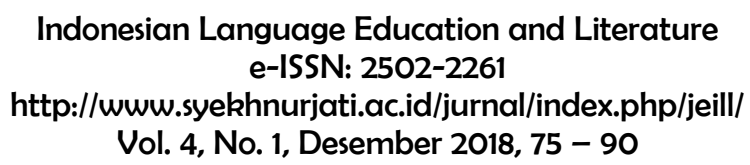

gabungan. Konjungsi ini mempunyai status sederajat bahwasanya Allah mengetahui segala yang ada di bumi dan langit. Konjungsi dan pada terjemahan termasuk konjungsi antarklausa, yaitu jenis konjungsi aditif (gabungan). Konjungsi ini mempunyai status sederajat, yaitu Allah maha mengetahui apa yang dilahirkan, baik itu ucapan maupun keturunan. Konjungsi dan pada terjemahan termasuk konjungsi antarklausa, yaitu jenis konjungsi aditif (gabungan). Konjungsi ini mempunyai status sederajat bahwa Allah mengetahui apa yang kamu sembunyikan.

\section{Ayat 40- 46 tentang dakwah kepada khalifah}

Hai Bani Israil, ingatlah akan nikmat-Ku yang telah Aku anugerahkan kepadamu, dan penuhilah janjimu kepada-Ku, niscaya Aku penuhi janji-Ku kepadamu; dan hanya kepada-Ku-lah kamu harus takut (tunduk).

Konjungsi dan pada terjemahan termasuk konjungsi antarkalimat, yaitu jenis konjungsi aditif (gabungan). Konjungsi ini mempunyai status sederajat untuk selalu ingat akan nikmat Allah. Konjungsi dan pada terjemahan termasuk konjungsi antarklausa, yaitu jenis konjungsi aditif (gabungan). Konjungsi ini mempunyai status sederajat, yakni penuhilah janji kepada Allah maka Allah juga akan memenuhi janji, hanya kepada Allahlah harus takut dan tiada yang lainnya.

Dan berimanlah kamu kepada apa yang telah Aku turunkan (Al Quran) yang membenarkan apa yang ada padamu (Taurat), dan janganlah kamu menjadi orang yang pertama kafir kepadanya, dan janganlah kamu menukarkan ayat-ayat-Ku dengan harga yang rendah, dan hanya kepada Akulah kamu harus bertakwa.

Konjungsi dan pada terjemahan termasuk konjungsi antarkalimat, yaitu jenis konjungsi aditif atau gabungan. Konjungsi ini penanda hubungan penambahan yang mempunyai status sederajat, bahwa Alquran diturunkan untuk membenarkan. Konjungsi dan pada terjemahan termasuk konjungsi antarklausa, yaitu jenis konjungsi aditif. Konjungsi ini mempunyai status sederajat dan penanda hubungan penambahan, yakni untuk tidak menukarkan ajaran Allah dangan hal-hal yang rendah. Konjungsi dan pada terjemahan termasuk konjungsi antarklausa, yaitu jenis konjungsi aditif. Konjungsi ini mempunyai status sederajat dan penanda hubungan penambahan, yakni hanya kepada Allah. Konjungsi dan pada terjemahan termasuk konjungsi antarkalimat, yaitu jenis konjungsi aditif. Konjungsi ini mempunyai status 


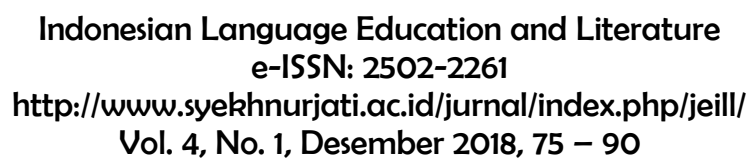

sederajat dan penanda hubungan penambahan, yakni hanya kepada Allah sematalah manusia bertakwa.

"Dan janganlah kamu campur adukkan yang hak dengan yang bathil dan janganlah kamu sembunyikan yang hak itu, sedang kamu mengetahui."

Konjungsi dan pada terjemahan termasuk konjungsi antarkalmat, yaitu jenis konjungsi aditif atau gabungan. Konjungsi ini mempunyai status sederajat dan penanda hubungan penambahan, yakni tentang ajaran jangan mencapuradukan yang hak dan yang bathil. Konjungsi dan pada terjemahan termasuk konjungsi antarklausa, yaitu jenis konjungsi aditif atau gabungan. Konjungsi ini mempunyai status sederajat dan penanda hubungan penambahan, yakni jangan menyembunyikan yang baik itu padahal kamu mengetahuinya.

Dan dirikanlah shalat, tunaikanlah zakat dan ruku'lah beserta orang-orang yang ruku'.

Konjungsi dan pada terjemahan Alquran termasuk konjungsi antarklausa, yaitu jenis konjungsi aditif atau gabungan. Konjungsi ini mempunyai status sederajat dan penanda hubungan penambahan, yaitu untuk anjuran mendirikan sholat. Konjungsi dan pada terjemahan termasuk konjungsi antarklausa, yaitu jenis konjungsi aditif atau gabungan. Konjungsi ini mempunyai status sederajat dan penanda hubungan penambahan, yakni anjuran mengikuti orang yang benar.

Mengapa kamu suruh orang lain (mengerjakan) kebaktian, sedang kamu melupakan diri (kewajiban) mu sendiri, padahal kamu membaca Al Kitab (Taurat)? Maka tidaklah kamu berpikir?

Konjungsi koordinatif sedang konjungsi menyatakan situasi atau keadaan, bahwa menyuruh orang lain melakukan sesuatu sedangkan diri sendiri melupakan. Konjungsi koordinatif padahal menyatakan konjungsi situasi atau keadaan, yakni membaca, tetapi tidak melakukan dan tidak berpikir.

"Jadikanlah sabar dan shalat sebagai penolongmu. Dan sesungguhnya yang demikian itu sungguh berat, kecuali bagi orang-orang yang khusyu'." 


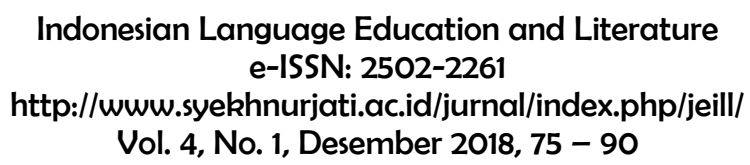

Konjungsi dan pada terjemahan Alquran termasuk konjungsi antarklausa, yaitu jenis konjungsi aditif. Konjungsi ini mempunyai status sederajat dan penanda hubungan penambahan, yakni untuk menjadi orang yang sabar. Konjungsi sesungguhnya pada terjemahan termasuk konjungsi antarklausa, yaitu terkait hubungan keadaan yang sebenarnya. Terjemahan ini menyatakan bahwa jangan jadikan salat itu berat, kecuali orang-orang yang khusyuk.

“... (yaitu) orang-orang yang meyakini, bahwa mereka akan menemui Tuhannya, dan bahwa mereka akan kembali kepada-Nya."

Konjungsi subordinatif bahwa menghubungkan antarklausa. Konjungsi ini menyatakan hubungan pengakibatan bertemu dengan yang kuasa untuk mempertangungjawabkan yang telah dilakukan. Konjungsi dan pada terjemahan Alquran termasuk konjungsi antarkalimat, yaitu jenis konjungsi aditif. Konjungsi ini mempunyai status sederajat dan penanda hubungan penambahan, yaitu untuk mengingatkan bahwa semuanya akan kembali kepada asalnya.

\section{Ayat 67-74 tentang menyembelih lembu betina}

Dan (ingatlah), ketika Musa berkata kepada kaumnya: "Sesungguhnya Allah menyuruh kamu menyembelih seekor sapi betina. Mereka berkata: "Apakah kamu hendak menjadikan kami buah ejekan? Musa menjawab: Aku berlindung kepada Allah agar tidak menjadi salah seorang dari orang-orang yang jahil.

Konjungsi dan pada terjemahan Alquran di atas termasuk konjungsi antarkalimat, yaitu jenis konjungsi aditif. Konjungsi ini mempunyai status sederajat dan penanda hubungan penambahan, yaitu anjuran mendirikan salat meyakini Allah. Konjungsi sesungguhnya pada terjemahan termasuk konjungsi antarklausa. Konjungsi ini mempunyai hubungan keadaan yang sebenarnya, yakni perintah untuk menyembelih sapi betina. Konjungsi subordinatif agar yang menandai hubungan tujuan, yaitu berlindung kepada Allah agar tidak menjadi orang yang jahil.

"Mereka menjawab: "Mohonkanlah kepada Tuhanmu untuk kami, agar Dia menerangkan kepada kami; sapi betina apakah itu." Musa menjawab: "Sesungguhnya Allah berfirman bahwa sapi betina itu adalah sapi betina yang tidak tua dan tidak muda; pertengahan antara itu; maka kerjakanlah apa yang diperintahkan kepadamu". 
Konjungsi subordinatif agar menandai hubungan tujuan, yakni memohon kepada Allah semata. Konjungsi sesungguhnya pada terjemahan termasuk konjungsi antarklausa. Konjungsi ini mempunyai hubungan keadaan yang sebenarnya, yakni perintah untuk menyembelih sapi betina yang tidak tua. Konjungsi dan pada terjemahan Alquran di atas termasuk konjungsi antarklausa, yaitu jenis konjungsi aditif. Konjungsi ini mempunyai status sederajat dan penanda hubungan penambahan, yakni anjuran menyembelih sapi yang tidak tua melainkan yang sedang. Hubungan sebab-akibat adalah hubungan sebab antara satu klausa dan klausa lain yang menyatakan akibat. Hubungan ini ditandai oleh penggunaan kata maka di depan klausa yang menyatakan akibat. (1) "Dan (ingatlah) ketika kami berfirman kepada para malikat: sujudlah kamu kepada Adam, maka sujudlah mereka kecuali Iblis; ia enggan dan takabur dan adalah is termasuk golongan orang-orang kafir (QS. Al-Baqarah: 34). Klausa anak berkonjungsi "maka" menyatakan makna akibat jadi konjungsi itu sesuai. Konjungsi subordinatif maka menandai hubungan pengakibatan, yakni mengerjakan hal yang diperintahkan oleh Allah.

"Mereka berkata: "Mohonkanlah kepada Tuhanmu untuk kami agar Dia menerangkan kepada kami apa warnanya". Musa menjawab: "Sesungguhnya Allah berfirman bahwa sapi betina itu adalah sapi betina yang kuning, yang kuning tua warnanya, lagi menyenangkan orang-orang yang memandangnya."

Konjungsi supaya atau agar menyatakan hubungan tujuan. Konjungsi ini menyatakan hubungan yang terdapat dalam klausa utama. Subordinator yang dipakai untuk menyatakan hubungan ini, meliputi: agar, agar supaya, serta supaya. Konjungsi subordinatif agar konjungsi antarkalimat menandai hubungan tujuan, yakni memohon kepada Allah petunjuk memyembelih sapi betina. Konjungsi sesungguhnya pada terjemahan termasuk konjungsi antarklausa. Konjungsi ini mempunyai hubungan keadaan yang sebenarnya, yakni perintah menyembelih sapi betina berwarna kuning dan menyenangkan dilihat orang.

"Mereka berkata: "Mohonkanlah kepada Tuhanmu untuk kami agar Dia menerangkan kepada kami bagaimana hakikat sapi betina itu, karena sesungguhnya sapi itu (masih) samar bagi kami dansesungguhnya kami insya Allah akan mendapat petunjuk (untuk memperoleh sapi itu)." 
Konjungsi subordinatif agar konjungsi anatarkalimat menandai hubungan tujuan, yakni memohon kepada Allah tentang penyembelihan sapi betina. Konjungsi dan pada terjemahan Alquran di atas termasuk konjungsi antarklausa, yaitu jenis konjungsi aditif. Konjungsi ini mempunyai status sederajat, yakni penanda hubungan penambahan. Adapun terjemahannya, umat belum mengerti tentang anjuran menyembelih sapi yang diperintahkan Allah. Konjungsi sesungguhnya pada terjemahan termasuk konjungsi antarklausa. Konjungsi ini mempunyai hubungan keadaan yang sebenarnya. Terjemahannya, Insyaah akan mendapatkan petunjuk tentang syarat penyembelihan sapi betina yang diperintahkan Allah.

Musa berkata: "Sesungguhnya Allah berfirman bahwa sapi betina itu adalah sapi betina yang belum pernah dipakai untuk membajak tanah dan tidak pula untuk mengairi tanaman, tidak bercacat, tidak ada belangnya." Mereka berkata: "Sekarang barulah kamu menerangkan hakikat sapi betina yang sebenarnya". Kemudian mereka menyembelihnya dan hampir saja mereka tidak melaksanakan perintah itu.

Konjungsi sesungguhnya pada terjemahan termasuk konjungsi antarklausa. Konjungsi ini mempunyai hubungan keadaan yang sebenarnya. Makna Insyaah akan mendapatkan petunjuk tentang syarat penyembelihan sapi betina yang diperintahkan Allah. Konjungsi dan pada terjemahan Alquran di atas termasuk konjungsi antarklausa, yaitu jenis konjungsi aditif. Konjungsi ini mempunyai status sederajat, yakni penanda hubungan penambahan. Terjemahannya berupa anjuran menyembelih sapi yang yang tidak cacat. Konjungsi antarkalimat kemudian menyatakan konjungsi kelanjutan adanya hal atau peristiwa. Kelanjutan dari suatu peristiwa atau keadaan yang diterangkan pada kalimat sebelumnya. Terjemahan itu tentang semuanya mengikuti perintah untuk menyembelih sapi betina.

"Dan (ingatlah), ketika kamu membunuh seorang manusia lalu kamu saling tuduh menuduh tentang itu. Dan Allah hendak menyingkapkan apa yang selama ini kamu sembunyikan."

Konjungsi dan pada terjemahan Alquran di atas termasuk konjungsi antarkalimat, yaitu jenis konjungsi aditif. Konjumgsi ini mempunyai status sederajat. Penanda hubungan yang dimaksud berupa penambahan, yakni tidaklah membunuh dan 


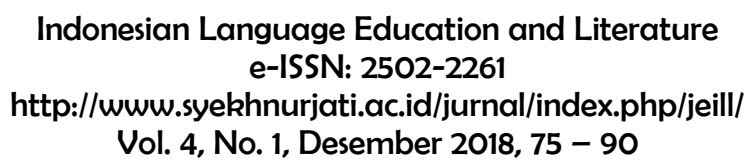

menuduh sesama. Konjungsi dan pada terjemahan Alquran di atas termasuk konjungsi antarklausa, yaitu jenis konjungsi aditif. Konjungsi ini mempunyai status sederajat dan penanda hubungan penambahan. Adapun yang dimaksud, yaitu ditutupi seperti apa pun suatu waktu perbuatan jahat itu akan diketahui juga. Allah mengetahui semua perbuatan umatnya.

Lalu Kami berfirman: "Pukullah mayat itu dengan sebahagian anggota sapi betina itu!" Demikianlah Allah menghidupkan kembali orang-orang yang telah mati, Dia memperlihatkan padamu tanda-tanda kekuasaanNya agar kamu mengerti.

Penggunaan konjungsi lalu yang menyatakan urutan akan sesuatu hal, yakni Allah akan menghidupkan kembali orang-orang yang sudah mati. Penggunaan konjungsi agar bermakna final atau tujuan yang menyatakan suatu peristiwa atau tindakan. Maknanya, Allah menyuruh umat untuk mengerti tanda-tanda kekuasaannya.

\section{SIMPULAN}

Berdasarkan analisis teks terjemahan surat Albaqarah juz 1, terdapat 22 penggunaan kata konjungsi. Konjungsi itu dapat dibagi menjadi dua kelompok, yakni koordinatif dan subordinatif. Konjungsi koordinatif menyatakan makna penambahan, pertentangan, kejadian, penjelas, pengecualian, dan pemilihan. Konjungsi subordinatif menyatakan makna penyebab, syarat, tujuan, batas akhir, dan penyungguhan. Terjemahan Surah Albaqarah mengandung konjungsi intrakalimat, yaitu konjungsi koordinatif dan subordinatif. Konjungsi koordinatif, meliputi: dan, lalu, tetapi, kemudian, bahwa, dan atau. Konjungsi subordinatif, meliputi: maka, agar, jika, jikalau, sebab, ketika, dengan, sebagaimana, dan sedang. Penggunaan konjungsi antarkalimat, meliputi: padahal, selain, lagi, serta, dan sesungguhnya. Konjungsi syarat atau kondisional jikalau.

\section{DAFTAR PUSTAKA}

Chaer, A. \& Agustina, L. (2004). Sosiolinguistik: Perkenalan Awal. Jakarta: PT Rineka Cipta.

Chaer, A. (2012). Linguistik Umum. Jakarta: PT Rineka Cipta.

Departemen Pendidikan Nasioal Republik Indonesia. (2008). Kamus Besar Bahasa Indonesia. Jakarta: Kemdikbud. 


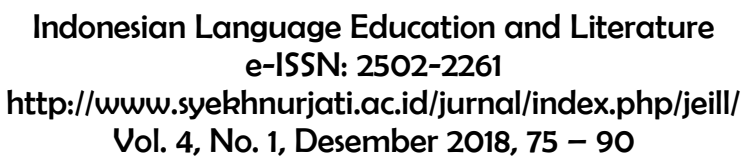

Fikri, A. A. (2014). Analisis Konjungsi Pada Terjemahan Surat An Nisa. 310100041, Markhamah, Jurusan Pendidikan Bahasa dan Sastra Indonesia, Fakultas Keguruan dan Ilmu Pendidikan, Universitas Muhammadiyah Surakarta.

Hartanto, B. (2015). Analisis Unsur Kohesi dalam Wacana Bahasa SMS (Short Message Service). Indonesian Language Education and Literature, 1(1), 90 - 106. DOI: http://dx.doi.org/10.24235/ileal.v1i1.74.

Hun, K. Y. \& Hassan, U. H. A. (2017). Dakwah, Wealth and Desire of Sexuality in Islam: The Concept of Love in Habiburrahman El-Shirazy's Ayat-Ayat Cinta 2. Indonesian Language Education and Literature, 2(2), 106 - 120. DOI: http://dx.doi.org/10.24235/ileal.v2i2.1458.

Moeliono, A. M. \& Dardjowidjojo, S. (1988). Tata bahasa baku Bahasa Indonesi. Jakarta: Departemen Pendidikan dan Kebudayaan.

Prastyaningsih, L. S. A. (2001) Ilmu Bahasa (Linguistik). Malang: FKIP Unisma.

Sari, D. M. (2010). Penggunaan Konjungsi Koordinatif Dalam Novel Kasih Tak Terlerai Karya Soeman Hs. Penggunaan konjungsi koordinatif dalam novel Kasih Tak Terlerai karya Suman Hs. Skripsi.

Ummi, H. U. \& Mulyaningsih, I. (2016). Penerapan Teori Konstruktivistik Pada Pembelajaran Bahasa Arab di Kelompok 28 Program Intensifikasi Bahasa Arab IAIN Syekh Nurjati Cirebon. Indonesian Language Education and Literature, 1(2), 162 - 172. DOI: http://dx.doi.org/10.24235/ileal.v1i2.600. 